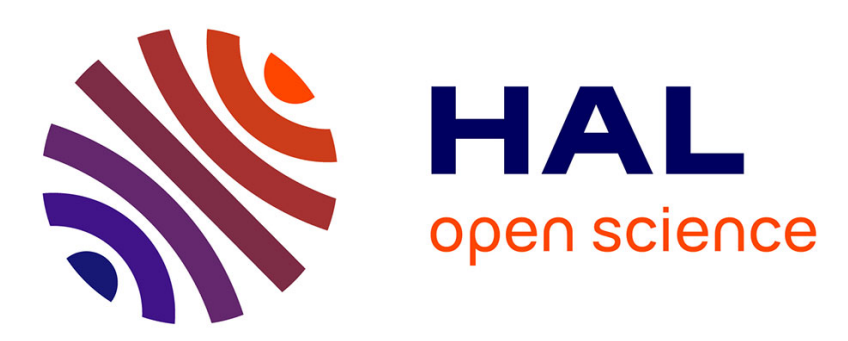

\title{
Management of groundwater resources in relation to oasis sustainability: The case of the Nefzawa region in Tunisia
}

\author{
Insaf Mekki, Frédéric Jacob, Serge Marlet, Wafa Ghazouani
}

\section{To cite this version:}

Insaf Mekki, Frédéric Jacob, Serge Marlet, Wafa Ghazouani. Management of groundwater resources in relation to oasis sustainability: The case of the Nefzawa region in Tunisia. Journal of Environmental Management, 2013, 121, pp.142-151. 10.1016/j.jenvman.2013.02.041 . hal-03413392

\author{
HAL Id: hal-03413392 \\ https://hal.science/hal-03413392
}

Submitted on 3 Nov 2021

HAL is a multi-disciplinary open access archive for the deposit and dissemination of scientific research documents, whether they are published or not. The documents may come from teaching and research institutions in France or abroad, or from public or private research centers.
L'archive ouverte pluridisciplinaire HAL, est destinée au dépôt et à la diffusion de documents scientifiques de niveau recherche, publiés ou non, émanant des établissements d'enseignement et de recherche français ou étrangers, des laboratoires publics ou privés.

\section{(ㄷ)(1) $\$$}

Distributed under a Creative Commons Attribution - NonCommerciall 4.0 International 


\title{
Management of groundwater resources in relation to oasis
}

\section{sustainability: The case of the Nefzawa region in Tunisia}

\author{
Insaf MEKKI ${ }^{\mathrm{a}}$, Frederic JACOB ${ }^{\mathrm{b}}$, Serge MARLET ${ }^{\mathrm{a}, \mathrm{c}}$, Wafa GHAZOUANI ${ }^{\mathrm{a}, \mathrm{c}}$
}

${ }^{a}$ INRGREF, Laboratoire Génie Rural, 2080 Ariana, Tunisia

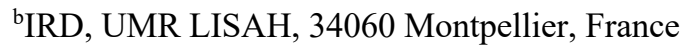

${ }^{\mathrm{c}}$ CIRAD, UMR G-EAU, 34033 Montpellier, France

\begin{abstract}
In Southern Tunisia Nefzawa region, the deep fossil aquifers have been used intensively to support agricultural activities and economic development. This resulted in the degradation of groundwater resources as well as in their conflicting uses. Efficient management strategies that allow for compromises between economic development and water resource preservation are needed. Such strategies require initial understanding of the interactions between stakeholders and water related processes. This paper aims to conceptualize the causalities between the management of deep fossil aquifers and the functioning of oasian agrosystems. By merging biophysical and socioeconomic issues, we propose an integrated assessment of public policies devoted to the management of groundwater resources. The failure of public policies emphasize both the lack of consideration for individual initiatives and the long-term uncertainties on such policies, where farmer practices have been driven by economic and cultural factors. A set of indicators is next proposed for assessing the preservation of deep fossil aquifers that support agricultural and economic development. Further methodological improvements are needed to evaluate the long-term effects of constraints and incentives on the management of deep fossil aquifers.
\end{abstract}

Keywords: Deep aquifer management, Driving forces - Pressures - States - Impacts - Responses framework, public policies, farmer strategies, oasian agrosystems, Tunisia. 


\section{Introduction}

Groundwater resources have significantly contributed to economic development and demographic growth in the past half century (Shah et al., 2007). However, this growth has occurred at the cost of increasing pressures on these water resources (Foster and Loucks, 2006; OSS, 2008; Jago-on et al., 2009). For example, high abstraction rates for groundwater resources have led to the depletion of aquifer levels (Ebraheem et al., 2003; Kamel et al., 2006). Although these effects have long been observed, pressures on groundwater resources have drastically increased in recent years due to human activities and rapid changes in land use. These pressures have been further intensified by government subsidies and easier access to drilling technologies (Hong et al., 2003; Zu et al., 2003; Wang et al., 2007).

Four types of arid and semiarid agrosystems depend entirely on groundwater resources (Shah et al., 2007): i) arid agricultural systems, such as in the Middle East and North Africa; ii) industrial agricultural systems, such as in Australia, southern Europe, and the western United States; iii) smallholder farming systems, such as in South Asia and the plains of Northern China; and iv) extensive pastoralism supported by groundwater, such as in Sub-Saharan Africa and Latin America. Public concerns are related to aquifer depletion and subsequent problems that induce desertification: poor agricultural management, water salinization and soil degradation (Feng et al., 2008; OSS, 2008; Saiko and Zonn, 2000; Zammouri et al., 2007; Huang and Pang, 2000). In the Mediterranean region, most oasian agrosystems with palm groves rely on deep fossil groundwater resources. These agrosystems constitute ancestral home lands and take part in cultural identities.

To improve water resource management, deep fossil aquifers have been studied intensively in attempts to provide diagnoses, prognostics, and potential solutions. Most studies have been limited to examinations of hydrogeological processes and modeling the water budgets of regional aquifer systems (Ebraheem et al., 2003; Kamel et al., 2006; Tang et al., 2007a,b; Zammouri et al., 2007; Hu et al., 2007). Nevertheless, studying the evolution of deep fossil aquifers requires consideration of human influences, which allows communities to be prepared for adaptation (Rapport and Singh, 2006; OSS, 2008). The challenge is to develop integrated approaches and evaluation tools, in order to characterize the causes and impacts of deep aquifer depletion (van Cauwenbergh et al., 2007; Ibanez et al., 2008). 
The biophysical and socioeconomic features of a given agrosystem, which result from public policies, collective management and individual behaviors, can be determined using synthetic indicators(Zalidis et al., 2004; van Cauwenbergh et al., 2007; Salvati and Zitti, 2009; Singh et al., 2009). The latter can be designed using causal frameworks, such as DPSIR (Driving forces - Pressures - States - Impacts - Responses), which was developed to define socioecological indicators (OECD, 1998; EEA, 1999). The DPSIR framework has been successfully applied to address various environmental issues, such as the sustainability of coastal areas (Bidone and Lacerda, 2004; Karageorgis et al., 2005), strategies for integrated water resource management at the catchment level (Giupponi et al., 2004), and, more generally, management issues related to seascapes and landscapes (Svarstad et al., 2008; Jago-on et al., 2009). Nevertheless, applying DPSIR to the management of deep fossil aquifers is not straightforward because diagnostic data are limited. Furthermore, the causes and impacts of deep aquifer depletion are neither obvious nor easy to assess (Konikow and Kendy, 2005; Foster and Loucks, 2006; Shah et al., 2007).

The aim of this paper is to analyze the causalities between the management of deep fossil aquifers and the functioning of oasian agrosystems by applying the DPSIR framework. The deep fossil aquifers considered in this study have provided a water supply for the oasian agrosystems of the Nefzawa region. On the one hand, these aquifers have experienced complex governance and management issues in relation to technological development, market liberalization of the date palm sector, and interferences between public policies and individual strategies. On the other hand, the Nefzawa region has experienced (i) changing policies for the management of land and non-renewable deep aquifer water resources, (ii) investments by national programs for agricultural modernization, and (iii) environmental and socioeconomic monitoring, which provides long-term datasets.

\section{Materials and methods}

\subsection{Study area: the Nefzawa oasian region}

\subsubsection{Biophysical characteristics}

The Nefzawa region is located in Kebili Governorate, southern Tunisia. It extends over a $2500 \mathrm{~km}^{2}$ area, from $33.3 \mathrm{~N}$ to $33.8 \mathrm{~N}$ latitude and from $8.5 \mathrm{E}$ to $9.0 \mathrm{E}$ longitude. Oases are scattered around Chott el-Djerid (Figure 1). The climate is arid (Sarfatti, 1988). Precipitation is concentrated in the winter, with annual values less than $100 \mathrm{~mm}$. 
[Figure 1 about here.]

In the vicinity of Chott el-Djerid, most soil from Nefzawa presents saline surface crusts. The variability in soil salinity mainly results from hydrological processes in relation to topography. Thus, oases are established over sand dunes, where shallow saline watertables result from poor natural drainage driven by outflows towards Chotts (El Fekih and Pouget, 1966), and from the inefficiency of artificial drainage systems (Luedeling et al., 2005; Marlet et al., 2009; Zammouri et al., 2007).

The water supply for Nefzawa stems from North Western Sahara Aquifer System (NWSAS), which includes Complex Terminal (CT) and Continental Intercalary (CI) aquifers (Zammouri et al., 2007). CT extends $670,000 \mathrm{~km}^{2}$, with a depth between 50 and $500 \mathrm{~m}$. CI covers a $1,100,000 \mathrm{~km}^{2}$ area and is located between 800 and $2500 \mathrm{~m}$ deep. CI geothermal water temperature is between 60 and $70^{\circ} \mathrm{C}$. Water resources were poorly quantified before 1970 . Since then, the NWSAS use has been planned and monitored, as a result of government initiatives that aimed to improve water resource management (ERESS, 1972).

Oasian crops within Nefzawa have long consisted of irrigated areas characterized by a canopy stratification that included a lower herbaceous layer, a middle fruit growing layer, and an upper date palm layer. The lower herbaceous layer is devoted to fodder crops with soil-enriching capacities through nitrogen binding. The Nefzawa oasian crops are characterized by traditional irrigation, where the main practice is flooding. Artesian or pumped water from NWSAS is brought by hydroagricultural infrastructures, such as cooling towers, ditches and water distribution networks.

\subsubsection{Socioeconomic context}

In the distant past, oases were established on artesian springs. Access to water resources was collective, free of charge and dependent on cultivated surfaces (Kassab, 1980). Irrigation was based on the water management rules of traditional communities via farmer assemblies that regulated water partitioning and resolved user conflicts (Trousset, 1987). In 1885, the Tunisian Government appropriated springs, thus dispossessing inhabitants from their ancestral and collective ownership (Attia, 1965). The end of the nineteenth century was characterized by an impoverishment of the agricultural sector inducing conflicts between inhabitants as well as emigration movements since the beginning of the 1970s (Sghaier, 2001). 
During the past half century, the Tunisian Government has implemented various incentives and regulations for the use of natural resources to sustain the economic development of the region. A summary of these incentives and regulations is presented in Table 1, along with their ongoing mutations. The land reform conducted between 1964 and 1969 faced opposition from most farmers and owners because of its collectivist dimension (Attia, 1965). The Water Code in 1975 completed the appropriation of water resources by the Government (Brochier-Puig, 2004).

[Table 1 about here.]

This period of incentives and regulations was characterized by the substitution of public structures into water user associations. These local water management institutions were under public directives and control. They experienced several changes in status and missions, simultaneously to both transfers of responsibilities and farmer involvements into collective water management. Such structures are currently labeled GDAs (French acronym for the Group for Agricultural Development). They are widespread within Nefzawa, with about 100 GDAs that collaborate closely with the regional institutions, so-called CRDA (French acronym for the Regional Planning for Agricultural Development).

This period of incentives and regulations was also characterized by the implementation of regional programs that focused on the use of groundwater resources, with different objectives. First, the PDES (French acronym for Southern Water Planning Program) program aimed to increase water abstraction and irrigated areas, while improving hydroagricultural infrastructures for water saving and soil preservation (Sghaier, 2001). Next, the APIOS (French acronym for Southern Oasis Irrigated Areas a Tunisian - Japanese program) project addressed the preservation of water resources through the modernization of distribution and drainage infrastructures, on the one hand, and the strengthening of institutional structures on the other hand (Ghazouani et al., 2009).

\subsection{Problem structuring}

\subsubsection{DPSIR presentation}


The DPSIR framework was designed to characterize causalities between social, economic and environmental components of complex systems, to make possible the organization of information about anthropogenic forcing, regardless of the ecosystem (Giupponi et al., 2004; Karageorgis et al., 2005;

Skoulikidis, 2009). By contributing to a better understanding of causalities through an integrated approach, DPSIR is a valuable tool for recommending possible strategies of ecosystem management (EEA, 1999). However, implementing DPSIR requires the collection of a large amount of information on the causalities between the anthropogenic forcing, the environmental consequences and the responses to environmental change (Jago-on et al., 2009).

The DPSIR framework is structured into five components that connect environmental processes and biophysical status with anthropogenic forcing (Mysiak et al., 2005; Svarstad et al., 2008): (i) driving forces represent the main socioeconomic factors that exert (ii) pressures on both the uses of natural resources and human activities, which cause changes in (iii) states of biophysical and socioeconomic environments, inducing (iv) impacts on ecosystem functioning that lead to (v) responses that feedback the driving forces, pressures, states and impacts. For a given ecosystem, DPSIR can be applied from different perspectives (e.g., water, soil or vegetation resources, resource quantity or quality, proposing recommendations or assessing policy impacts).

\subsubsection{Data collection}

The dataset used for implementing DPSIR involved two spatial scales in relation to biophysical and socioeconomic issues of groundwater resource management. The Nefzawa regional scale corresponded to the management of water resources by the CRDA institutional service in charge of managing deep aquifer boreholes and sharing discharge between oases. The oasis scale corresponded to the management of community water resources by the GDA water user association in charge of water distribution among farmers. For the local scale, the focus was the $1 \mathrm{~km}^{2}$ Fatnassa oasis, located northwest of Nefzawa (Figure 1).

To quantify the water abstraction into the CT and CI aquifers on the regional Nefzawa scale, long-term measurements (1970-2008) were obtained from the CRDA units in charge of managing the CT and CI boreholes. Data of water discharge and salinity levels for 2007 were provided by the CT and CI boreholes monitoring stations (CRDA-Kebili, 2007). Because these datasets were restricted to official records, they did not reflect uncontrolled abstractions from illicit wells. The resulting database 
was mostly fragmentary, and the gathered information was analyzed to ensure data reliability. Thus, we verified the borehole characteristics (salinity and abstraction levels, assigned oases and related extents, irrigated areas). Data on harvested date palm areas in Tunisia were obtained from FAO statistical reports (FAOSTAT, 2009). Statistics on total date production between 1984 and 2006 were obtained from the Tunisian Ministry of Agriculture. The diversity of farming systems was characterized using data from a previous study that included farm size, plot number and size, and crop types (Sghaier, 2001). These data were collected through farmer interviews by considering a household sample that represented $20 \%$ of the entire population.

On the Fatnassa local scale, shallow watertable depth and salinity level were measured on 165 field plots. Characteristics of the irrigated areas were obtained from the official land register of the GDA (GDA-Fatnassa, 2005), and next updated. The statistics included the number of farmers and plots, the member identities, the irrigation duration per plot, and the irrigated surface area. Data on cropping intensification and diversity at the parcel plot were estimated from in-situ observations. Date palm yields at the parcel plot scale were estimated at harvest time from field observations and expert knowledge. Data on farmers' perceptions and adaptation strategies were collected from individual and semi-directed on-farm interviews. The household sample represented 5\% of the population. Farmers were interviewed about (i) their perceptions of the environmental status, (ii) their perceptions of the malfunctioning of irrigation water management, and (iii) their adaptations to water shortage and soil degradation. The whole set of data collected at the Fatnassa local scale was analyzed in the framework of the SIRMA (French acronym for Water Saving in Maghreb Irrigated Areas, a project granted by the French Foreign Affairs Ministry) project (Ghazouani et al., 2009; Marlet et al., 2009; Bouarfa et al., 2009; Ghazouani et al., 2012).

For the data provided by technical and statistical reports from national and international program, as well as those provided by bibliographical materials from previous studies, a reference list is provided in the second bibliography section, "Administrative reports and other sources of data".

\subsubsection{DPSIR implementation}

Since the beginning of the 1970s, emigration resulted from an impoverished agricultural sector and job opportunities in cities and littorals (Sghaier, 2001). To prevent an economic collapse of the southern Tunisia oasian agrosystems, the Tunisian government significantly invested in agricultural 
intensification by initiating the PDES program in 1976. This intensification consisted of expanding irrigated areas and strengthening hydroagricultural infrastructures to mobilize water resources. Despite successes in terms of economic development, several environmental and societal problems were noted a posteriori (SAPI-team, 2005). To overcome these problems, the Tunisian government initiated the APIOS program, which focused on implementing strategies to improve the technical, economic and institutional dimensions of water resource management.

From the perspective of managing deep fossil aquifers within the Nefzawa oasian agrosystems, the DPSIR components are identified, along with their causal relationships (Figure 2), in relation to public strategies and resulting impulsions (i.e., regulations, incentives). The main drivers included socioeconomic dimensions (e.g., market constraints, technological developments), which generated pressures on deep fossil aquifers (water abstraction). These aquifers subsequently experienced damages such as salinization and lowering of the piezometric level. The resulting effects included agricultural, environmental and social damages, such as reduced agricultural performance and conflicts related to community water management. The response mechanisms were characterized by public policies and individual adaptation strategies, which induced feedback on the driving forces, pressures, states and impacts within the DPSIR framework.

[Figure 2 about here.]

\section{Results}

\subsection{Groundwater mobilization to stimulate economic growth}

\subsubsection{Driving forces}

When addressing the management of deep fossil aquifers within the Nefzawa oases, the driving forces can be differentiated into demography, market constraints, public regulations and farmers' strategies for water access and land tenure.

The Nefzawa population doubled over the last 30 years. This growth, combined with improvements in lifestyle, has resulted in increasing pressures on water resources. On the other hand, emigration has led to the lack of labor force in the agricultural sector as well as agricultural investments from emigrates (Bou Ali, 1988; Sghaier, 2001). 
Market liberalization for the export of palm dates has oriented farmers' practices toward the cultivation of remunerative varieties. Various local species have disappeared due to their inappropriateness for the market, and have been replaced by Deglet Nour variety. The latter now represents $75 \%$ of date production within Nefzawa. Opportunities on the Deglet Nour export market have led to the illicit expansion of irrigated areas with increasing rates of water abstraction.

The Tunisian Government implemented land privatization policies to promote individual investment and ownership. These policies have facilitated land tenure and the expansion of irrigated areas, with consequences to ownership rights for water resources. In an arid context where water possession have prevailed over land ownership (Trousset, 1987), access to land implies legal and / or illegal water mobilization. Thus, encouraging land possession led to violations of protection laws for deep aquifers. Figure 3 shows that from 1970 to 2008 (i) the oasian harvested area in southern Tunisia increased fivefold, and (ii) the total water abstraction increased fivefold. Partial information for water abstraction is due to difficulties in monitoring actual abstraction, especially from illicit wells.

Oasis area within Nefzawa increased from 7000 ha to more than16000 ha. These expansions and creations were conducted gradually according to the oasis type and period, where $40 \%$ of the oasis creations and expansions were unofficial. These illegal expansions are now observed in two-thirds of the oases, with ratios of extended to total areas ranging between $5 \%$ and $80 \%$. Two extreme instances in southern Nefzawa are the Nouiel oasis in 1995, with 100 ha of official areas amongst 650 ha of illegal expansion (Auclair and Zaafouri, 1996), and the El Faouar oasis expansion, with a total area of 86 ha in 2000 and 300 ha in 2007 (Brochier-Puig, 2004; CRDA-Kebili, 2007). .

[Figure 3 about here.]

In Nefzawa, most farmers own several very small fields distributed within the oases. This land fragmentation has sociocultural origins, with regulations for the succession and partitioning of irrigated lands within and outside the public organization (Brochier-Puig, 2004). The average farm area does not exceed 0.35 ha, with areas smaller than 0.25 ha for almost $80 \%$ of the farms and areas larger than 0.5 ha for approximately $10 \%$ of the farms (Sghaier, 2001). In Fatnassa oasis, 500 land owners share 470 parcels over 112 ha, with parcel areas ranging from 0.01 ha to 2 ha (with an average of 0.3 ha), of which $70 \%$ have areas smaller than 0.3 ha and only $2 \%$ have areas larger than 1 ha. 


\subsubsection{Pressures}

Both the increasing number of drillings into the NWSAS and the exploitation mode have led a significant withdrawal rate that increased from $0.6 \mathrm{Tm}^{3}$ year-1 in 1970 to $2.5 \mathrm{Tm}^{3}$ year-1 in 2000 (OSS, 2008). Available estimates suggest the number of illicit wells increased from several dozen in the 1970s to 1500 in the 1990s and 3500 today (Gharbi, 2010).

Figure 3 underlines three specific periods for water abstraction between 1970 and 2008. The first decade was characterized by a $50 \%$ increase in abstraction. This increase corresponded to the creation of new oases, the replacement of springs with wells in old oases, and the establishment of deep drilling into the CI aquifer along with a cooling tower (Belhedi, 1998). The second period extended through the 1980 s and 1990 s, when the abstraction increased by $250 \%$ due to official drillings and illicit wells. The 1980s saw the creation of 685 official drillings into the CT and CI aquifers and the emergence of illicit wells from which abstraction increased sevenfold (Sghaier, 2001). The 1990s saw the creation of 766 official drillings in $\mathrm{CT}$ and $\mathrm{CI}$ aquifers and the end of artesianism from the CT aquifer (Zammouri et al., 2007).After 2000, the increase in abstraction was moderate. The CT exploitation was more controlled because most of the created drillings (559) were connected to the CI aquifer which has provided approximately $32 \mathrm{Mm}^{3} \mathrm{year}^{-1}$ under strong artesian conditions.

\subsubsection{States}

The increasing use of deep fossil aquifers led to a strong decline in overall piezometric level and water quality degradation. For the $\mathrm{CT}$ aquifer, the depletion on the Nefzawa regional scale was about $1 \mathrm{~m}$ year $^{-1}$ from 1970 to 2000 (Mamou and Kassah, 2000). This depletion was convergent with the elimination in 1995 of natural springs that represented up to $30 \%$ of the water resources in the 1970 s (Kassab, 1980). Declines in CT groundwater levels led to the salinization of water resources because of the saline water upwelling from the underlying $\mathrm{CI}$ aquifer and the back-flow from shallow groundwater (Zammouri et al., 2007). From 1980 to 2000, salinity increased by 1-2 $\mathrm{g} \mathrm{l}^{-1}$ in the Kebili Peninsula and by more than 3-4 $\mathrm{g} \mathrm{l}^{-1}$ in the southern Douz region. Consequently, the water pumped at these locations was no longer suitable for irrigation (El-Fahem, 2003).

A decrease in the deep aquifer level reduced the discharge to oases' irrigation networks and increased the salinity levels at most measurement locations. Figure 4 shows the 2007 mean values of: (i) available discharge, calculated from forage deliveries and irrigated surface areas (CRDA-Kebili, 
2007), and (ii) salinity of irrigation water, measured at forage deliveries for several oases in Nefzawa. The discharge was highly variable, with a coefficient of variation of $35 \%$ for a mean value of $0.851 \mathrm{~s}^{-1}$ $\mathrm{ha}^{-1}$. When compared to the date palm minimum requirement $\left(0.71 \mathrm{~s}^{-1} \mathrm{ha}^{-1}\right)$, the discharge was lower for $40 \%$ of the oases (with a minimum of $0.31 \mathrm{~s}^{-1} \mathrm{ha}^{-1}$ ), between 0.8 and $11 \mathrm{~s}^{-1} \mathrm{ha}^{-1}$ for $31 \%$ of the oases, and greater than $11 \mathrm{~s}^{-1}$ ha-1 for $29 \%$ of the oases. Locally, the salinity reached $7 \mathrm{~g} \mathrm{l}^{-1}$, and exhibited significant spatial variability, with a coefficient of variation of $40 \%$ for a mean value of $2.6 \mathrm{~g}$ $\mathrm{I}^{-1}$. This variability was also observed at the Fatnassa oasis, with measured values between $1.2 \mathrm{~g} \mathrm{l}^{-1}$ and $5.8 \mathrm{~g}^{-1}$.

[Figure 4 about here.]

\subsubsection{Impacts}

Subsequently to the shortage of groundwater resources, three types of effect were identified: (i)salinization of soil and waterlogging, (ii) conflicting situations in relation to water resource management, and (iii) a decline in agricultural performance.

Salinization of soil and waterlogging stemmed (i) from shallow saline watertables due to excessive irrigation with saline water from deep fossil aquifers and (ii) from deficiencies in artificial drainage due to channel clogging by sand and roots (Ben Aissa, 2006). In the Fatnassa oasis, the salinity of drainage water varies from 8 g. $\mathrm{l}^{-1}$ in winter to $25 \mathrm{~g} . \mathrm{l}^{-1}$ in summer, while waterlogging induces root asphyxiation (Marlet et al., 2009). Farmers mitigate both effects by conducting sand and manure supplies. More drastic adaptations include abandoning old salinized and waterlogged plots while developing plantations on new parcels (Ghazouani et al., 2009). For the Fatnassa oasis, farmland abandonment in the ancient section is as high as $12 \%$.

Despite the implementation of water user associations, collective water resource management has suffered from several problems, with subsequent conflicts among water users. Problems arise from the water shortage due to deep fossil aquifer depletion, particularly from low efficiency of water distribution. Local conflicts result from inequities in water distribution, including individual behaviors that extend the duration of irrigation to overcome extended water turns (Ghazouani et al., 2009). For Fatnassa, the average duration of irrigation exceeds the $10 \mathrm{~h} \mathrm{ha}^{-1}$ rule by $80 \%$ (Ghazouani et al., 2012). This corresponds to a 30- to 60-day duration for water turns, compared to 5-day duration in the 1970s. 
Low agricultural performance is mainly caused by summer water shortages resulting from the lengthening of water turns and the decreased discharge for irrigation schemes. Poor performance includes lower cropping intensities, lower date yields and lower date quality. Figure 5 shows the evolution of date production in southern Tunisia. Annual production increased twofold from 1980 to 2006, with 55\% originating in Nefzawa. This increase resulted from a rise in cultivated areas (Figure 3), whereas yields tended to decrease. Yields are extremely variable in time and space, with values ranging between 2 and 5 tons ha ${ }^{-1}$. Such variability is also observed between total and first quality yields, with respective values of 4.9 and 2.3 ton.ha $^{-1}$ in Fatnassa in 2007.

[Figure 5 about here.]

\subsection{Responses: promotion of water resource preservation}

The driving forces, pressures, states and impacts (DPSI) presented above have led to public and individual responses (R), with feedback from the latter on the former (Figure 2). The DPSI components have lasted for decades, leading to a temporal overlap with the R components (Table 1). The latter encompass public policies and farmers' individual strategies for adaptation, in an attempt to (i) offer feedback on biophysical and socioeconomic states, (ii) mitigate pressures on groundwater resources and (iii) improve socioeconomic and environmental conditions.

\subsubsection{Public policies: the APIOS program}

The aim of the APIOS program was motivated by the impossibility of increasing water supply. The alternative was to improve the technological (e.g., hydraulics) and socioeconomic (e.g., management) dimensions of water use. Thus, significant investments were made to modernize hydro-agricultural infrastructures and transform water community management.

Modernizing hydroagricultural infrastructures consisted of concreting irrigation canals to reduce seepage and save water, and burying drainage networks to mitigate soil waterlogging and salinization (STUDI and BRL-Ingénierie, 1999). Simultaneously, subsidies of up to $60 \%$ of the expenses were proposed to encourage farmers to install water saving infrastructures (irrigation basins, PVC pipes) at the plot level. These actions were conducted from 2000 to 2005 over 3700 ha within Nefzawa (Gharbi, 2010). 
Monitoring networks were established for soil salinization and waterlogging problems to predict effects and propose management strategies. To mitigate the deep aquifer depletion, a $50 \mathrm{~m}$ critical depth was established, below which groundwater pumping was strictly controlled. To avoid local excessive pumping into deep aquifers, the abstraction rate was limited to the range of 100-300 1.s1 for new wells.

These public actions were strengthened by the implementation during the 1990s of various administrative regulations, technical solutions and management support programs (Table 1). However, farmers' strategies have conflicted with the implementation of public policies and regulation measures, since local adaptations have often diverged from institutional plans.

\subsubsection{Individual and collective strategies}

Farmers' adaptation strategies have aimed to mitigate several constraints on agricultural activities: (i) the high costs of pumping water, (ii) underestimations in assigned irrigated surfaces compared to farm sizes and subsequent needs, (iii) high export demands for Deglet Nour production, and (iv) deficient infrastructures for irrigation and drainage.

Individual responses include expanding irrigated areas and implementing illicit drillings, which result in a spiral of increasing demand and decreasing availability of water resources. These expansion strategies benefit from public policies that accept to integrate a posteriori the illicit plantations into water management schemes (e.g., 15\% of illicit expansions in Fatnassa during APIOS).

Farmers' perceptions of water resources from deep fossil aquifers appear to be unrealistic, with the belief that CRDA and GDA structures should provide the required water supply. During the summer water shortage caused by the water turn extending to 60 days, inappropriate practices include the following: (i) the use of highly salinized water from shallow watertables and drainage networks, to be diluted with official water allocations, (ii) the use of illicit drillings into the CT aquifer, and (iii) the lengthening of irrigation durations per plot.

\section{Discussion and conclusion}

The Nefzawa oasian agrosystems rely on deep fossil aquifers for their agricultural water supply. The resulting exploitation of these aquifers, increased fourfold between 1970 and 2000 (OSS, 2008), and led to quantitative and qualitative degradations of water resources. Public policies were initially 
oriented toward aquifer exploitation for economic growth and then reshaped toward aquifer preservation. However, it was not possible to obtaining significant advances in water resource management because of widespread individual behaviors, such as expanding irrigated areas and establishing illicit wells for additional irrigation. Farmers with private expansions now beseech the authorities to maintain illicit areas, which are productive but threatened by salinization, waterlogging and summer water shortage. This is tolerated by the authorities because of strong social pressure and the lack of alternative solutions. The competitive use of water resources on regional and oasis scales is also observed at the transnational level because of the extent of the NWSAS over Tunisia, Algeria and Libya.

The failure of public policies devoted to regulating the use of water resources from deep fossil aquifers highlights both the lack of consideration for individual initiatives when establishing such policies and the long-term uncertainties when implementing them. From this perspective, the Nefzawa oasian agrosystems constitute a case in which farmers' practices are driven by various factors (cultural perceptions of access to land and water resources, demography and technological development), with subsequent changes in the actors' behaviors that mitigate public actions.

From the perspective of groundwater management, the DPSIR approach used here facilitates understanding of the causalities between several biophysical and socioeconomic components and between different types of interactions. The DPSIR framework also relies on several simplifications resulting from a condensed representation of a complex system, especially when addressing human activities and their consequent forcing on natural resources. Methodological improvements are required that rely on adequate spatiotemporal scales, normalized observations, and deeper characterizations of agrosystem biophysical and socioeconomic functioning.

From the perspective of evolution scenarios for the Nefzawa oasian agrosystems, another benefit of implementing DPSIR is the identification of first-order influences for the design of biophysical and socioeconomic indicators in relation to anthropogenic pressures and agrienvironmental and economic performance (Zalidis et al., 2004; Bidone and Lacerda, 2004). Below, we propose such indicators for the Nefzawa oasian agrosystems.

From a biophysical perspective, four potential indicators are identified. The first indicator is land use and land cover change in relation to farmland expansion and / or abandonment. This change can be monitored using high spatial resolution solar remote sensing and geographical information 
systems (Ming et al., 2008). Such information on irrigated areas is important to indirectly quantify water abstraction into deep fossil aquifers. The second indicator is water abstraction, which can be directly monitored by the GDA, although the official land register do not include illicit expansions.

Another possibility is indirect monitoring by thermal infrared remote sensing of evapotranspiration, if drainage can be estimated (Jhorar et al., 2011). The third indicator is water productivity derived from the date palm yield, which permits to monitor agricultural performance by integrating several components of cropping system management. However, the relevance of this indicator is secondary to the quality of information on the irrigation water supply and yields. The fourth indicator of deep fossil aquifers is the piezometric level and water flow regulation, expressed in terms of flow per area unit, to be regionally aggregated. However, changes in deep aquifer level and quality are difficult to monitor due to experimental issues (Jago-on et al., 2009).

From a socioeconomic perspective, two potential indicators are identified. The first indicator is land ownership and fragmentation, which drive agricultural practices and water use management at the plot level (Section 3.1.4). This indicator would facilitate monitoring of the consequences of recent public policies that encourage the reduction of land fragmentation by regulating sales and inheritances (Table 1). However, estimating this indicator is very difficult because of significant differences between official information and actual situations. Land ownership is usually poorly documented, and individual property does not indicate systematic self-cultivation because emigrated owners bequeath to employees who do not determine investments and strategies. The second indicator is water delivery frequency, which is strongly influenced by the balance between individual behaviors and collective management schemes. This indicator would be valuable for assessing, for instance, the effect of water price on water use regulation where such a public policy is often presented as an efficient mechanism when it accounts for agrosystem specificities, although it must be promoted because farmers perceive it as an inconvenient issue (Fiorillo et al., 2007).

Overexploitation of deep fossil groundwater resources is becoming a global problem within the Nefzawa region, because of consequences on agricultural performances. In addition, inheritance processes for smallholders with low incomes face the lack of motivation from successors because of attractive opportunities in other sectors. A sustainable management of groundwater resources that allows for long lasting of oasian agrosystems requires revising public policies. Several types of responses can be foreseen at different scales according to the involved stakeholders. 
- Setting up adaptive legislations for (i) regulating sales and inheritances by thresholding minimum parcel size, (ii) encouraging parcel merging and (iii) restricting illicit expansions.

- Implementing regulation measures that enable the control of water abstraction, while accounting for conflicts between regulation policies and traditional property rights

- Reinforcing the role of GDAs to enhance their administration and financial autonomies when relaying governmental measures.

- Promoting both innovative irrigation practices that optimize water supply and drainage systems that mitigate soil salinization and waterlogging.

- Facilitating crop diversification for mitigating dependences upon date export market, and beyond facilitating the integration of tourism based activities for diversifying sources of income. 


\section{Acknowledgments}

This paper is a contribution of the SIRMA project (www.eau-sirma.net), funded by the French Ministry of Foreign Affairs. The authors wish to thank the Tunisian Ministry of Agriculture, the CRDA Kebili, the GDA Fatnassa, the French Institute of Research for Development (IRD) and the French International Cooperation Center in Agronomic Research for Development (CIRAD) for their support.

\section{References}

Attia, H., 1965. State control of water resources in oasis of the Tunisia Jerid region. History of a dispossession. In: State, territories and countries in Maghreb. CNRS editions, Paris, pp. 361-375, (in French).

Auclair, L., Zaafouri, M. S., 1996. Nomad settlements in southern Tunisia: energetic behaviors and desertification. Sécheresse 7, 17-24, (in French).

Belhedi, A., 1998. Strategies and counter-strategies for development problems in Souk Lahad (Nefzawa). In: Oases in Maghreb, valuations and developments, CERES books, geographical series. Vol. 12. pp. 229-246, (in French).

Ben Aissa, I., 2006. Performance assessment for a buried drainage network within a modernized oasis in southern Tunisia: the case of the North-Fatnassa oasis in Kébili. Master's thesis, Montpellier II University, France, (in French).

Bidone, E., Lacerda, L., 2004. The use of DPSIR framework to evaluate sustainability in coastal areas. Case study: Guanabara Bay basin, Rio de Janeiro, Brazil. Regional Environmental Change 4, 5-16.

Bossel, H., 2001. Assessing viability and sustainability: a systems-based approach for deriving comprehensive indicator sets. Conservation Ecology 5, 2-12.

Bou Ali, S., 1988. Man and oasis: demography, migrations and employments in oasian systems: a case study in the Jerid and Nefzawa regions in Tunisia. Mediterranean Options: Series A. Mediterranean seminaries 11, 277-288, (in French).

Bouarfa, S., Marlet, S., Douaoui, A., Hartani, T., Mekki, I., Ghazouani, W., Ben Aissa, I., Vincent, B., Hassani, F., Kuper, M., 2009. Salinity patterns in irrigation systems, a threat to be demystified, a constraint to be managed: field evidence from Algeria and Tunisia. Irrigation and Drainage 58, S273-284 
Brochier-Puig, J., 2004.Water uses in oases under urbanization process: the case study of Nefzawa in southern Tunisia. Transforming territories. Journal of CNRS UMR5045 "Mutations in European Territories", Montpellier III University 11, (in French).

Ebraheem, A. M., Garamoon, H. K., Riad, S., Wycisk, P., Seif El Nasr, A. M., 2003. Numerical modeling of groundwater resource management options in the East Oweinat area, SW Egypt. Environmental Geology 44, 433-447.

EEA, 1999. Environmental indicators: typology and overview, report no. 25. Tech.rep., European Environmental Agency, Copenhagen.

El-Fahem, T., 2003. Salination of Groundwater in the Nefzawa Oases - South Tunisia.Tech. rep., Institute of Hydromechanics and Water Resources, Swiss Federal Institute of Technology and Institute of Engineering Geology and Hydrogeology, Rhenian Westphalian University of Technology Aachen.

El Fekih, M., Pouget, M., 1966. Soils of ancient oases in southern Tunisia. In: Mediterranean soils. p. 11 p. multigr., (in French).

Feng, S., Kang, S., Huo, Z., Chen, S., Mao, X., 2008. Neural networks to simulate regional ground water levels affected by human activities. Ground Water 46, 80-90.

Fiorillo, F., Palestrini, A., Polidori, P., Socci, C., 2007. Modelling water policies with sustainability constraints: A dynamic accounting analysis. Ecological Economics 63, 392-402.

Foster, S., Loucks, D. (Eds.), 2006. Non-Renewable Groundwater Resources. A guide book on socially-sustainable management for water-policy makers. HIP-VI, Series on Groundwater. UNESCO, Paris.

Gharbi, N., 2010. Hydraulic infrastructures and improvement of water management in southern oases. In: Marlet, S., Mekki, I. (Eds.), Proceedings of the SIRMA workshop "Natural resources management and sustainable development of Nefzawa oasian systems". Cirad, Douz, Tunisie, 5 p., (in French).

Ghazouani, W., Marlet, S., Mekki, I., Harrington, L. W., Vidal, A., 2012. Farmers’ Practices and Community Management of Irrigation: Why do they not match in Fatnassa Oasis?. Irrigation and Drainage, 63, 39-51. 
Ghazouani, W., Marlet, S., Mekki, I., Vidal, A., 2009. Farmers' perceptions and engineersapproach in a community-managed irrigation scheme. A case study from anoasis of the Nefzawa (South of Tunisia). Irrigation and Drainage 58, S285-S296.

Giupponi, C., Mysiak, J., Fassio, A., Coganc, V., 2004. MULINO-DSS: a computer tool for sustainable use of water resources at the catchment scale. Mathematics and Computers in Simulation 64, 13-24.

Hong, Z., Jian-Wei, W., Qiu-Hong, Z., Yun-Jiang, Y., 2003. A preliminary study of oasis evolution in the Tarim Basin, Xinjiang, China. Journal of Arid Environments 55, 545-553.

Hu, L.T., Chen, C.X., Jiao, J. J., Wang, Z.-J., 2007. Simulated groundwater interaction with rivers and springs in the Heihe river basin. Hydrological Processes 21, 2794-2806.

Huang, T., Pang, Z., 2000. Changes in groundwater induced by water diversion in the Lower Tarim River, Xinjiang Uygur, NW China: Evidence from environmental isotopes and water chemistry. Journal of Hydrology 387, 188-201.

Ibanez, J., Valderrama, J., Puigdefabregas, J., 2008. Assessing overexploitation in Mediterranean aquifers using system stability condition analysis. Ecological modeling 218, 260-266.

Jago-on, K., Kaneko, S., Fujikura, R., Fujiwara, A., Imai, T., Matsumoto, T., Zhang, J., Tanikawa, H., Tanaka, K., Lee, B., Taniguchi, M., 2009. Urbanization and subsurface environmental issues: An attempt at DPSIR model application in Asian cities. Science of the Total Environment 407, 30893104.

Jhorar, R. K., Smit, A., Bastiaanssen, W., Roest, C., 2011. Calibration of a distributed irrigation water management model using remotely sensed evapotranspiration rates and groundwater heads. Irrigation and Drainage 60, 57-69.

Kamel, S., Dassi, L., Zouari, K., 2006. Hydrogeological and hydrochemical approachfor hydrodynamic exchanges between deep and shallow aquifers in the Djerid basin,Tunisia. Hydrological Sciences Journal 5, 713-730, (in French).

Karageorgis, A., Skourtos, M., Kapsimalis, V., Kontogianni, A., Skoulikidis, N., K., P., Nikolaidis, N., Drakopolou, P., Zanou, B., Karamanos, H., Levkov, Z., Anagnostou,C., 2005. An integrated approach to watershed management within the DPSIR framework: Axios River catchment and Thermaikos Gulf. Regional Environmental Change 5, 138-160.

Kassab, A., 1980. Problems in Tunisian oases. Rural studies in Tunisia, Tunis Faculty of Letter and Human Sciences, second series: Geography VI, 391-412, (in French). 
Konikow, L., Kendy, E., 2005. Groundwater depletion: A global problem. Hydrogeology Journal 13, $317-320$.

Luedeling, E., Nagieb, M., Wichern, F., Brandt, M., Deurer, M., Buerkert, A., 2005.Drainage, salt leaching and physico-chemical properties of irrigated man-made terrace soils in a mountain oasis of northern Oman. Geoderma 125, 273-285.

Mamou, A., 1984. Hydrogeological resources and agricultural development in southernTunisia. In: Baduel, P. (Ed.), Sahariens stakes. CNRS, pp. 267-274, (in French).

Mamou, A., Kassah, A., 2000.Water saving and resource valuation in Tunisia. Sécheresse11, 249-256, (in French).

Marini, C. M., Ongaro, L., 1988. Mapping Nefzawa oases: an example of satellite imagery analysis. Rivista di Agricoltura Subtropicale e Tropicale LXXXII (1-2),91-102, (in Italian).

Marlet, S., Bouksila, F., Bahri, A., 2009. Water and salt balance at irrigation scheme scale: A comprehensive approach for salinity assessment in a Saharan oasis. Agricultural water management 96, 1311-1322.

Ming, G., Wenbing, Y., Mingguo, M., Xin, L., 2008. Study on the oasis landscape fragmentation in northwestern china by using remote sensing data and GIS: a case study of jinta oasis. Environmental Geology 54, 629-636.

Mysiak, J., Giupponi, C., Rosato, P., 2005. Towards the development of a decision support system for water resource management. Environmental Modelling and Software20, 203-214.

OECD, 1998. Towards Sustainable Development: Environmental Indicators. Tech.rep., Organization for Economic Cooperation and Development.

OSS, 2008. The North-Western Sahara Aquifer System (Algeria, Tunisia, Libya): joint management of a transborder water basin. Synthesis collection no 1, Sahelian and Sahel Observatory, Tunis.

Rapport, D., Singh, A., 2006. An ecohealth-based framework for state of environment reporting. Ecological Indicators 6, 409-428.

Saiko, T., Zonn, I., 2000. Irrigation expansion and dynamics of desertification in the Circum-Aral region of Central Asia. Applied Geography 20, 349-367.

Salvati, L., Zitti, M., 2009. Assessing the impact of ecological and economic factors on land degradation vulnerability through multiway analysis. Ecological Indicators 9, 357-363. 
Sarfatti, P., 1988. Climate of the Kébili governorate in Tunisia. Rivista di Agricoltura Subtropicale e Tropicale LXXXII (1-2), 23-36, (in Italian).

Sghaier, M., 2001. Socio-economic research in the continental oases of Tunisia (Fatnassa).In: de Haas, H. (Ed.), Migration, Agricultural Transformations and Natural Resource Exploitation in the Oases of Morocco and Tunisia, Final Scientific Report imarom Research Project to the European Commission. Amsterdam: University of Amsterdam, pp. 207-228.

Shah, T., Burke, J., Villholth, K., 2007. Groundwater: a global assessment of scale and significance. In: Molden, D. (Ed.), Water for Food, Water for Life: A Comprehensive Assessment of Water Management in Agriculture. Earthscan, London, UK and IWMI, Colombo, Sri Lanka, pp. 395-423.

Singh, R., Murty, H., Gupta, S., Dikshit, A., 2009. An overview of sustainability assessment methodologies. Ecological Indicators 9, 189-212.

Skoulikidis, N., 2009. The environmental state of rivers in the balkans- a review within DPSIR framework. Science of the Total Environment 407, 2501-2516.

STUDI, BRL-Ingénierie, 1999. Improvement project for irrigated perimeters within southern oases. The Kébili project. First part, Phase I, Volume 2, Fatnassa Oasis.Tech. rep., STUDI and BRLIngénierie, (in French).

Svarstad, H., Petersen, L. K., Rothman, D., Siepel, H., Watzold, F., 2008. Discursive biases of the environmental research framework DPSIR. Land Use Policy 25, 116-125.

Tang, Q., Hu, H., Oki, T., Tian, F., 2007a. Water Balance within Intensively Cultivated Alluvial Plain in an Arid Environment. Water Resources Management 21, 1703-1715.

Tang, Q., Hu, H., Taikan, O., 2007b. Groundwater recharge and discharge in a hyper arid alluvial plain (Akesu, Taklimakan Desert, China). Hydrological Processes 21, 1345-1353.

Trousset, P., 1987. Oasis organization during Antiquity: example of Gabès and Djerid region. In: de Reparaz, A. (Ed.), Water and mankind in the Mediterranean basin. CNRS, Centre Régional de Publication de Marseille (Paris- Marseille, pp. 25-41,(in French).

van Cauwenbergh, N., Biala, K., Bielders, C., Brouckaert, V., Franchois, L., Cidad,V. G., Hermy, M., Mathijs, E., Muys, B., Reijnders, J., Sauvenier, X., Valckx, J.,Vanclooster, M., der Veken, B. V., Wauters, E., Peeters, A., 2007. Safe-a hierarchical framework for assessing the sustainability of agricultural systems. Agriculture, Ecosystems and Environment 120, 229 - 242. 
Wang, J., Miller, D. R., Sammis, T. W., Gutschick, V. P., Simmons, L. J., Andales, A.,2007. Energy balance measurements and a simple model for estimating pecan water use efficiency. Agricultural water management 91, 92-101.

Zalidis, G. C., Tsiafouli, M. A., Takavakoglou, V., Bilas, G., Misopolinos, N., 2004.Selecting agrienvironmental indicators to facilitate monitoring and assessment of EU agri-environmental measures effectiveness. Journal of Environmental Management 70, 315-321.

Zammouri, M., Siegfried, T., El-Fahem, T., Samiha, K., Kinzelbach, W., 2007. Salinization of groundwater in the Nefzawa oases region, Tunisia: results of a regional scale hydrogeologic approach. Hydrogeology Journal 15, 1357-1375.

Zu, R., Gao, Q., Qu, J., Qiang, M., 2003. Environmental changes of oases at southern margin of Tarim Basin, China. Environmental Geology 44, 639-644.

\section{Administrative reports and other sources of data}

CRDA-Kebili, 2007. Annual report of 2007 activities. Tech. rep., Regional planning Commission for Agricultural Development, Kebili Tunisia, (in French).

ERESS, 1972. Study about Northern Sahara water resources. Tech. rep., UNESCO, Paris, (in French).

FAOSTAT, March 2009. Data on date palm oases production in Tunisia between 1961 and 2007.URL http://faostat.fao.org/site/567/DesktopDefault.aspx?PageID=567\#ancor(access_date_march_2009)

GDA-Fatnassa, 2005. Land register and identity list of the Fatnassa GDA members. Tech. report.

SAPI-team, 2005. Irrigation perimeter improvement project for oases in Southern Tunisia. Tech. rep., DG/GREE, Tunisian Ministry of Agriculture, Tunis. 


\section{List of Figures}

1. Map of the Nefzawa oasian region, from Marini and Ongaro (1988). Chotts are dry salt lakes. The Fatnassa oasis is located at the far northwestern border of Nefzawa. It is indicated with a square that includes the labels "N" and "S" for Northern and Southern parts. The Kebili peninsula is located in northwestern Nefzawa.

2. Implementation of the DPSIR framework from the perspective of managing deep fossil aquifer resources within the Nefzawa oasian agrosystems in southern Tunisia. Continuous lines represent the direct links between DPSIR components. Dashed lines represent the feedback of the response on each of the D-P-S-I components.

3. Evolution, between 1970s and 2008, of the: (i) harvested area for date palm in Southern Tunisia, (ii) water abstraction $\left(\mathrm{m}^{3} \mathrm{~S}^{-1}\right)$ into the $\mathrm{CT}$ and $\mathrm{CI}$ aquifers for the water supply of Nefzawa oases. Abstraction includes official and illicit areas, where pumping for illicit areas is an estimate. Data from Mamou (1984); Sghaier (2001), the Tunisian Ministry of Agriculture (general directory for water resources, and FAO statistical reports (FAOSTAT, 2009).

4. Average of: (i) available discharge (1..-1.ha-1), and (ii) irrigation water salinity (total dissolved solids, g.1-1) in several Nefzawa oases in 2007. From CRDA-Kebili (2007).

5. Date palm production and yield evolution in Tunisia between 1984 and 2006. Data from Tunisian Ministry of Agriculture, Fruit Inter- Professional Association. 


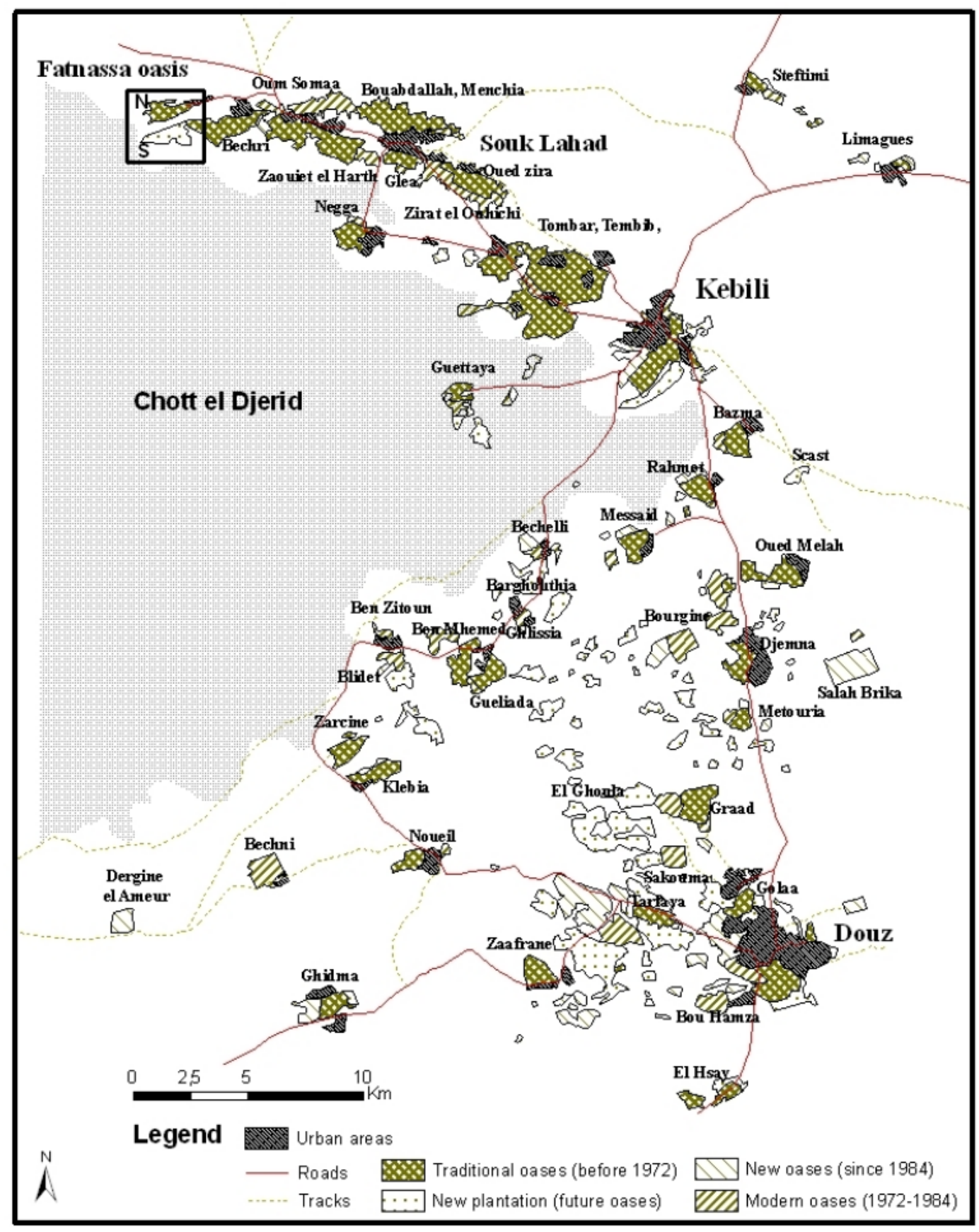

Figure 1. Map of the Nefzawa oasian region, from Marini and Ongaro (1988). Chotts are dry salt lakes. The Fatnassa oasis is located at the far northwestern border of Nefzawa. It is indicated with a square that includes the labels "N" and "S" for Northern and Southern parts. The Kebili peninsula is located in northwestern Nefzawa. 


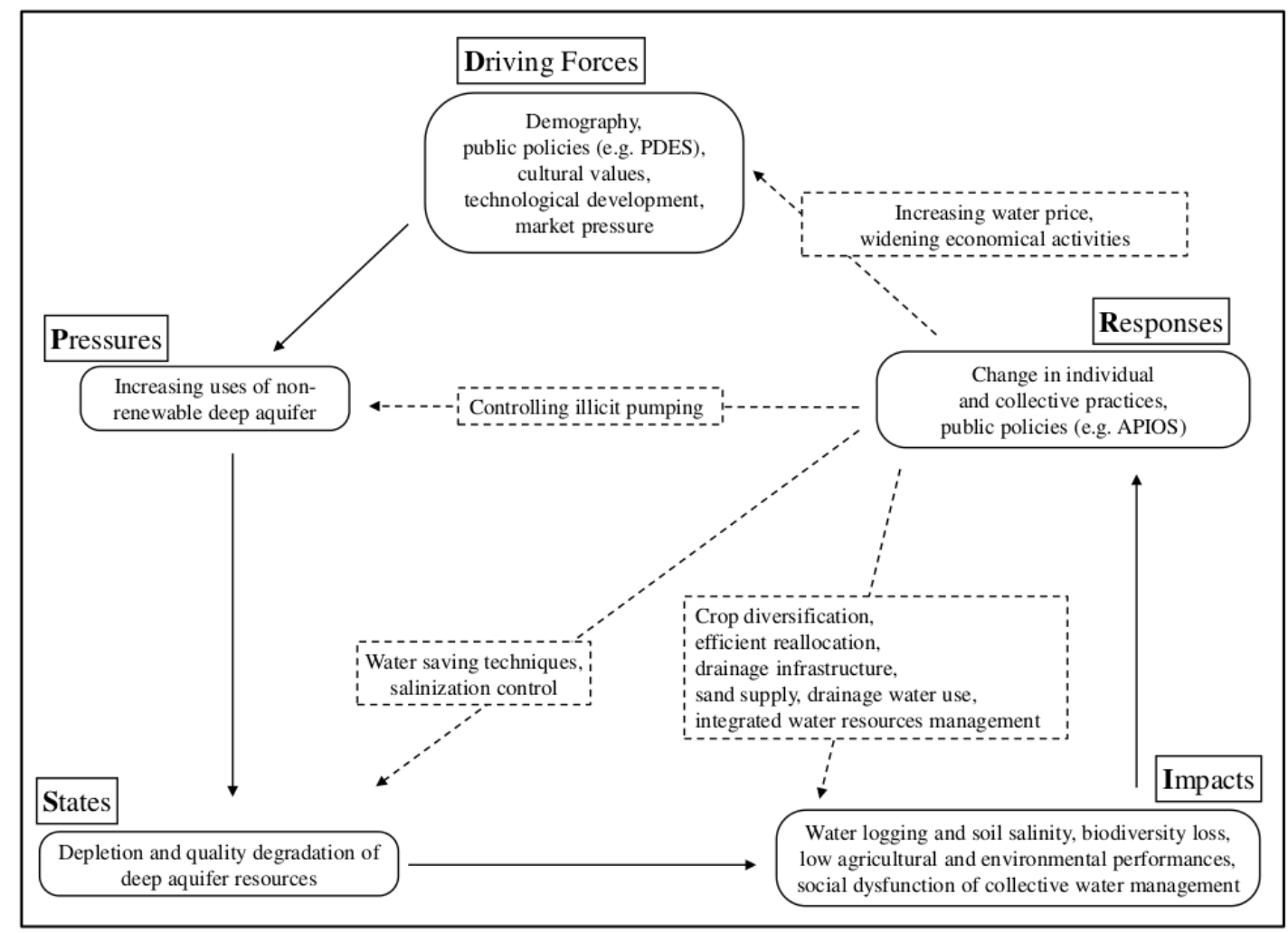

Figure 2. Implementation of the DPSIR framework from the perspective of managing deep fossil aquifer resources within the Nefzawa oasian agrosystems in southern Tunisia. Continuous lines represent the direct links between DPSIR components. Dashed lines represent the feedback of the response on each of the D-P-S-I components. 


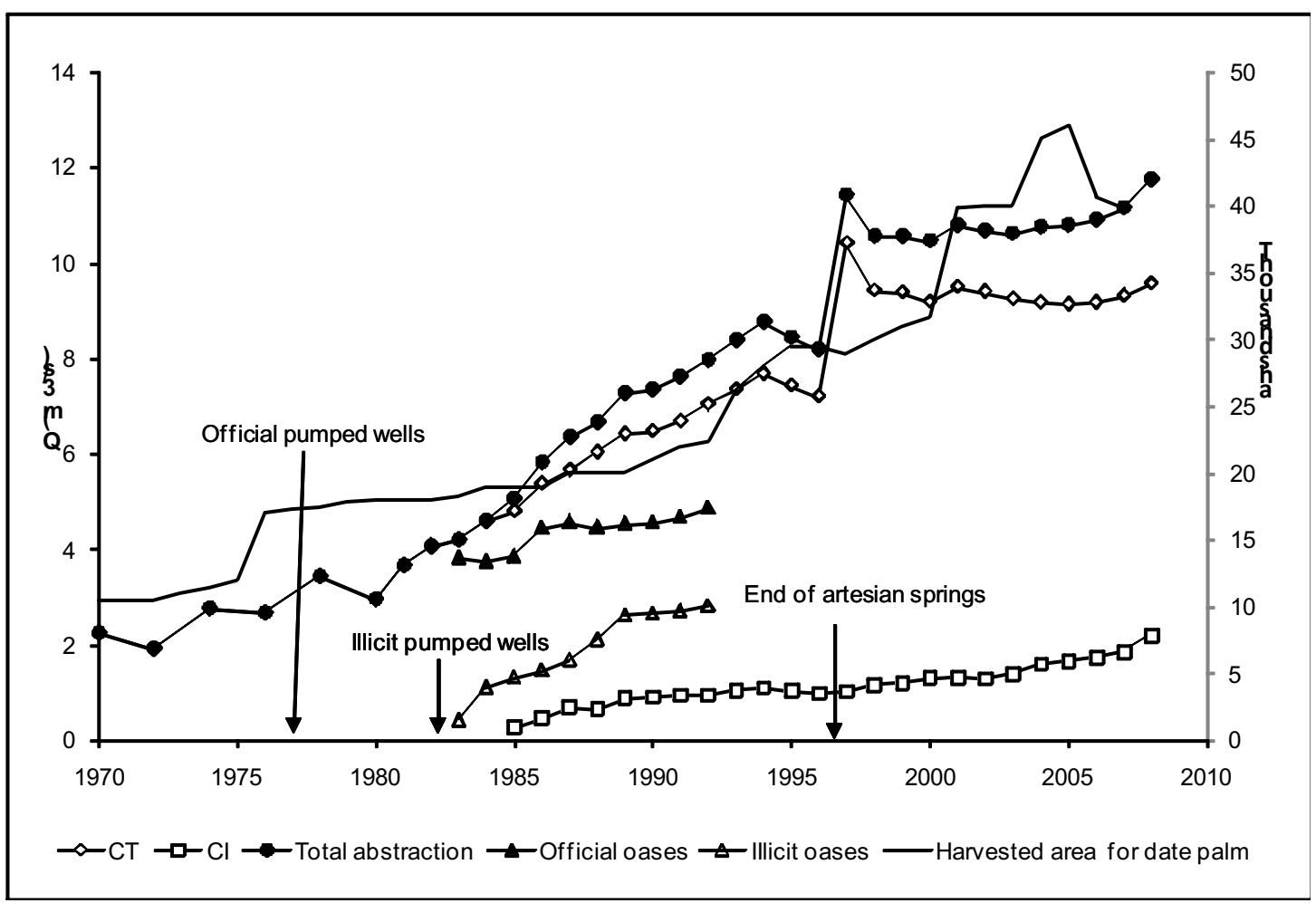

Figure 3. Evolution, between 1970s and 2008, of the: (i) harvested area for date palm in Southern Tunisia, (ii) water abstraction $\left(\mathrm{m}^{3} \cdot \mathrm{s}^{-1}\right)$ into the $\mathrm{CT}$ and CI aquifers for the water supply of Nefzawa oases. Abstraction includes official and illicit areas, where pumping for illicit areas is an estimate. Data from Mamou (1984); Sghaier (2001), the Tunisian Ministry of Agriculture (general directory for water resources, and from FAO statistical reports (FAOSTAT, 2009). 


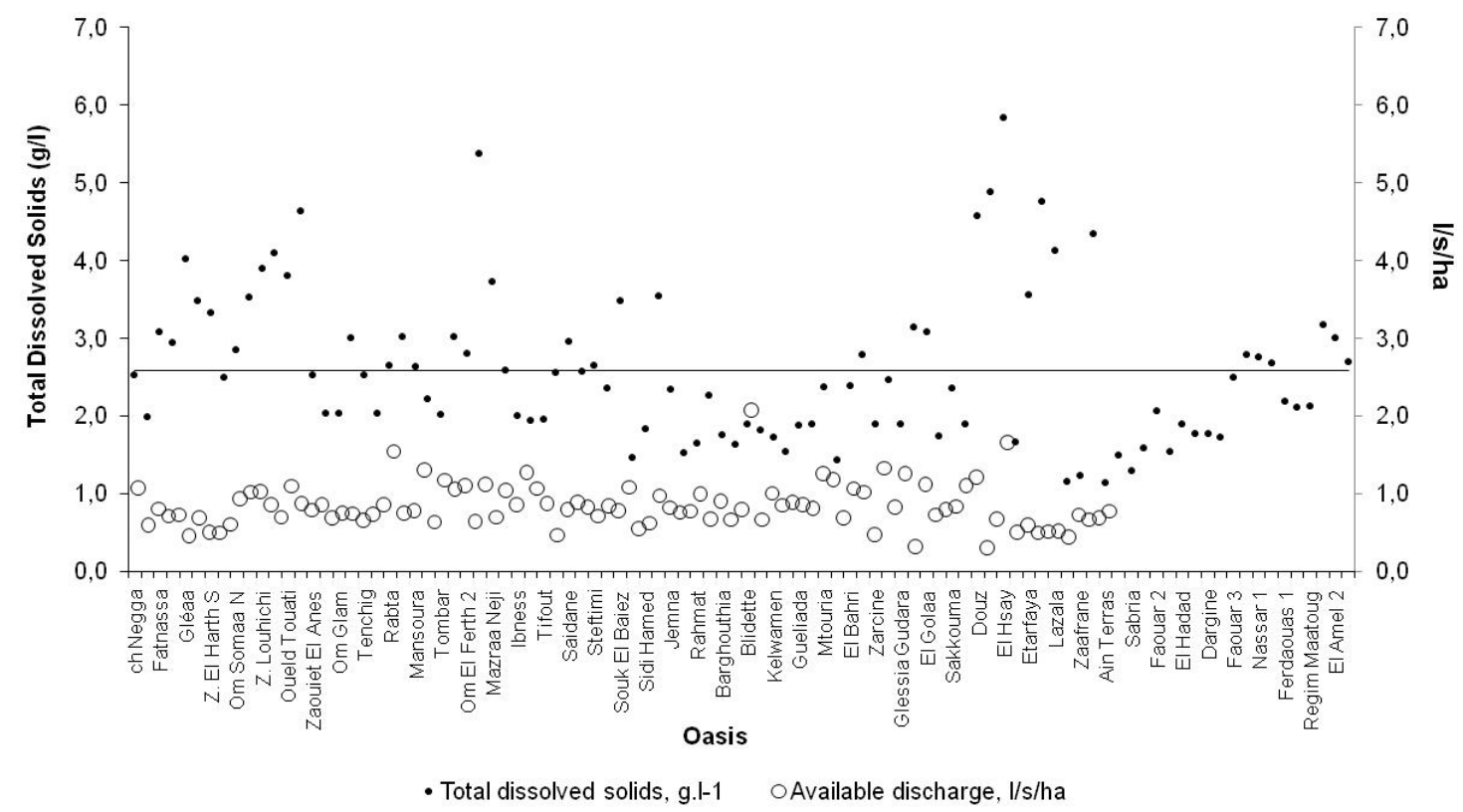

Figure 4. Average of: (i) available discharge $\left(1 . \mathrm{s}^{-1} \cdot \mathrm{ha}^{-1}\right)$, and (ii) irrigation water salinity (total dissolved solids, g.1-1) in several Nefzawa oases in 2007. From CRDA-Kebili (2007). 


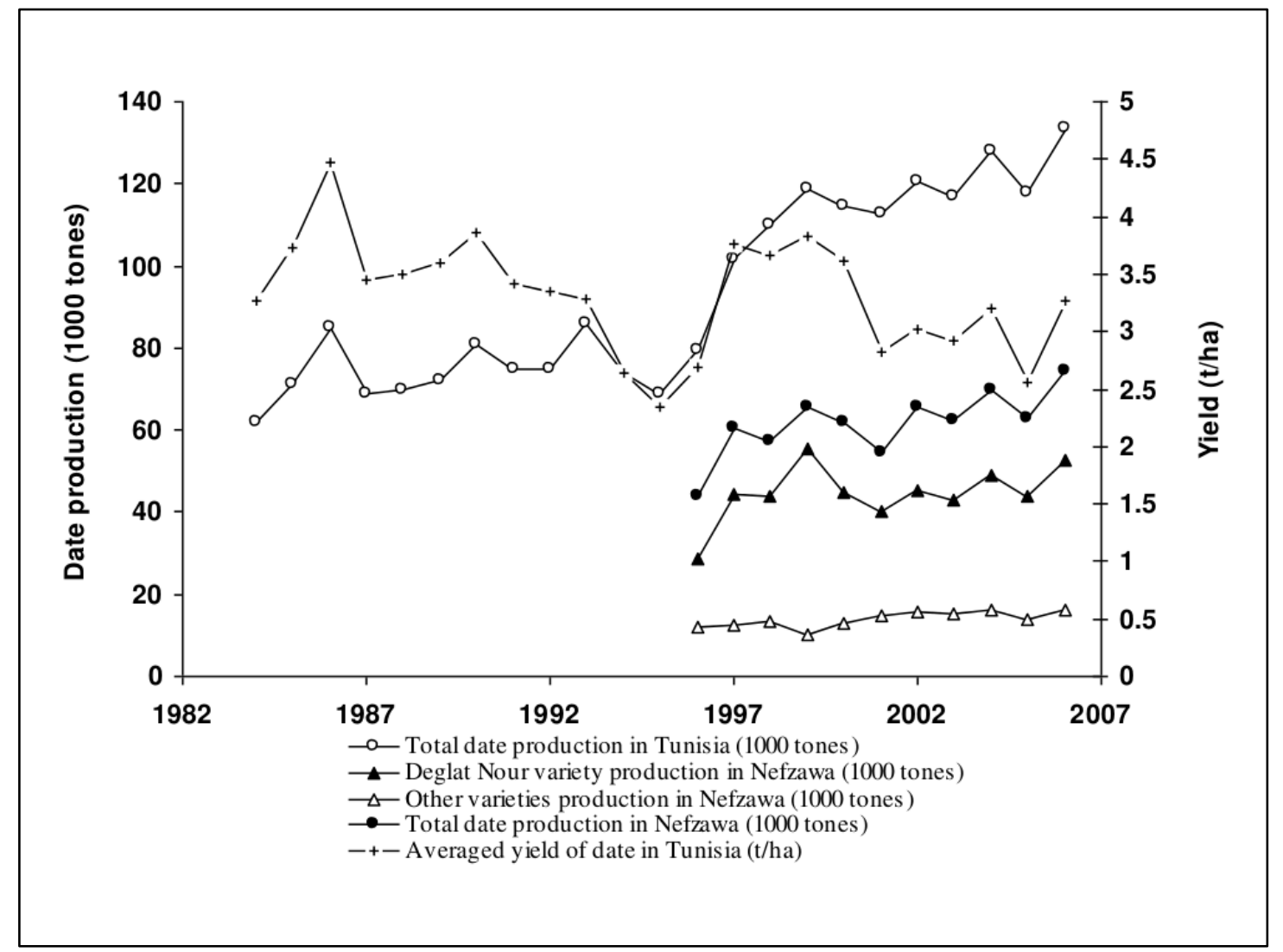

Figure 5. Date palm production and yield evolution in Tunisia between 1984 and 2006. Data from Tunisian Ministry of Agriculture, Fruit Inter- Professional Association. 


\section{List of Tables}

1. Major public strategies, public regulations / incentives and related mutations that have driven the management of water resources from deep fossil aquifers. 
Table 1. Major public strategies, public regulations / incentives and related mutations that have driven the management of water resources from deep fossil aquifers.

\begin{tabular}{|c|c|c|c|}
\hline $\begin{array}{l}\text { Period } \\
\text { \& strategy }\end{array}$ & Year & Regulations and incentives & Mutations \\
\hline $\begin{array}{l}1950-1970 \\
\text { Settling nomad } \\
\text { populations. }\end{array}$ & $\begin{array}{l}1964 \rightarrow \\
1969\end{array}$ & $\begin{array}{l}\text { Individual property of collective land: farmers } \\
\text { allowed to cultivate abandoned farmlands and } \\
\text { deserts for agriculture. } \\
\text { Traditional community rules for land tenures } \\
\text { and water access regulations. } \\
\text { Collectivization experience: oppositions from } \\
\text { most farmers and land owners. }\end{array}$ & $\begin{array}{l}\text { Migration from } \\
\text { countries to cities } \\
\text { for jobs in tourism } \\
\text { and industry. } \\
\text { Depletion of artesian } \\
\text { flows. }\end{array}$ \\
\hline $\begin{array}{l}1970-1990 \\
\text { Increasing } \\
\text { water offer for } \\
\text { economic } \\
\text { development. }\end{array}$ & $\begin{array}{l}1976 \\
1989\end{array}$ & $\begin{array}{l}\text { Hydrological understanding of the NWSAS } \\
\text { groundwater system. Planning and monitoring } \\
\text { of its use. } \\
\text { Liberalization of date market, inducing changes } \\
\text { in land access and use. } \\
\text { Structuration of the professional sector, } \\
\text { implementation of marketing management. } \\
\text { Implementation of water code: transition from } \\
\text { traditional water property rights to water use } \\
\text { rights. } \\
\text { PDES program: public investments for the use } \\
\text { of water resources. } \\
\text { Implementing regional scale management of } \\
\text { water resources with CRDA institutions. }\end{array}$ & 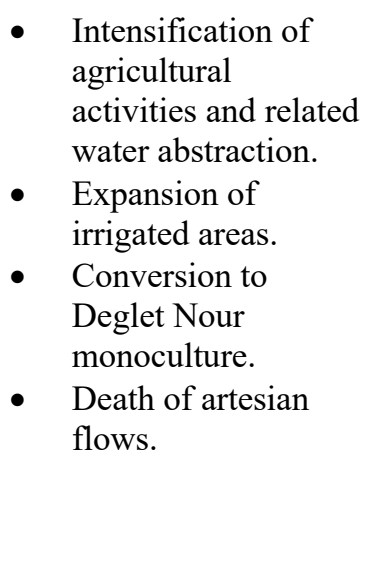 \\
\hline $\begin{array}{l}\text { 1990-2010 } \\
\text { Managing } \\
\text { water use for } \\
\text { Sustainable } \\
\text { development. }\end{array}$ & $\begin{array}{l}1994 \rightarrow \\
2005 \\
2007\end{array}$ & $\begin{array}{l}\text { Modernizing hydro-agricultural infrastructures. } \\
\text { Shifting local management from public to user } \\
\text { structures with water user associations. } \\
\text { APIOS program: public investments for } \\
\text { strengthening technical, economical and } \\
\text { institutional issues of water management. } \\
\text { Decentralizing oasis management with local } \\
\text { structures for land and water use (GDA). } \\
\text { International agreement between users of } \\
\text { NWSAS water resources (Algeria, Libya, } \\
\text { Tunisia), including a permanent dialog. } \\
\text { Legislation for reducing land fragmentation } \\
\text { and prohibiting illicit pumping. } \\
\text { Extending water saving techniques and } \\
\text { participative water management. } \\
\text { Promoting the protection of the natural } \\
\text { resources against degradation. }\end{array}$ & $\begin{array}{l}\text { - Intensification of } \\
\text { agricultural } \\
\text { activities. } \\
\text { - Increasing of water } \\
\text { use efficiency. } \\
\text { - Increased } \\
\text { preservation of soil } \\
\text { and water (shallow } \\
\text { and deep aquifers) } \\
\text { resources. }\end{array}$ \\
\hline
\end{tabular}

NWSAS: Northwestern Sahara Aquifer System.

PDES: French acronym for the Southern Water Planning Program.

CRDA: French acronym for the Regional Planning Commission for Agricultural Development.

APIOS: French acronym for Improving Southern Oasis Irrigated Perimeters, a Tunisian-Japanese project.

GDA: French acronym for the Group for Agricultural Development. 